\title{
An Assessment of Recreational Functions of Botanical Parks in Urban Ecosystems
}

\section{Nilufer Seyidoglu Akdeniz ( $\nabla$ nilsem@yahoo.com )}

Bursa Uludağ Üniversitesi: Bursa Uludag Universitesi https://orcid.org/0000-0001-6789-4473

\section{S. Doganay Yener}

İstanbul Üniversitesi-Cerrahpaşa: Istanbul Universitesi-Cerrahpasa

\section{Research Article}

Keywords: Recreational Quality, Botanic Park, Public Participation, Urban ecosystem, İstanbul/Turkey

Posted Date: December 6th, 2021

DOI: https://doi.org/10.21203/rs.3.rs-1101256/v1

License: (c) (i) This work is licensed under a Creative Commons Attribution 4.0 International License. Read Full License 


\section{Abstract}

In the changing world, pandemics have entered human life and people want to relieve the stress and relax that these new living conditions they meet. Parks in the urban ecosystem are one of the indispensable elements in this sense. In this context, while botanical parks contribute to the urban ecosystem, they also meet the recreational needs of people.In this study, a survey was carried out for assessing the recreational quality of Bakırköy Botanical Park in Bakırköy, Istanbul, which is Turkey's most important metropolitan city. The results of the survey reveal that the users perceived Bakırköy Botanical Park as an urban park, and the findings reveal that young users (26-35 years old) visited the park mostly within 1-3 hours. In addition to being a park to get away from the crowd (78.00\%) in terms of comfort and image, the presence of children's playgrounds is also considered an important recreational function for users $(66.80 \%)$. Although the park has some deficiencies in terms of reinforcement elements and negligence, observations exhibited that it cannot fulfill its education and research functions adequately as a botanical park. Hence, the plants in the park must have labels. It would be an appropriate approach to make the necessary arrangements for Bakırköy Botanical Park to maintain both its recreational and educational functions, and to consider the protection-use balance in the arrangements.

\section{Introduction}

People living in the cities need natural environments and urban green areas more due to factors such as the concretion of work and home environments, environmental pollution, and traffic problems (Turna et al. 2017). While green areas offer positive effects on human health and psychology, they also offer a natural habitat by regulating the microclimate of the city. To improve the living environment quality of citizens, the urban architects interested in designing the green urban areas seeking natural sanctuaries to relax, rejuvenate, and enjoy nature (Chiesura 2004; Millera et al. 2015). As an example of these places, where individuals meet both their personal and social recreational needs, parks, squares, pedestrian zones, cemeteries, playgrounds, zoos, and botanical gardens can be given (Hepcan and Özkan, 2005). The park is defined as a place that includes different attributes to characterize itself and decide its appearance to attract its customers (Stanford and Guiver, 2015). The authors observed that parks enhance the quality of life by increasing the degree of enjoyment and satisfaction experienced in daily life. At parks, visitors fulfill their own goals of self-identity and social bonding (Lee and Shen, 2013), finding balance in their psychological, physical, and economic wellbeing (Razak et al. 2016). Among the park areas, botanical gardens stand out with their versatile benefits. Today the roles are including the activities such as recreational activities, social activities, economic activities, etc. Botanic gardens also play the roles as a part of the green lung of the city that gives freshness for the visitors in the metropolitan city (Mat Nazir et al. 2014) With their rich collections and scientific resources, botanical gardens have a unique potential that attracts the attention of society to the problems of preserving biodiversity, ensuring environmental education, conserving nature, providing leisure, and serving the place for relaxation and entertainment (Kalugin et al. 2019). According to the definition of Heywood, President of the Botanic Gardens Conservation International, botanical gardens are the organizations that grow the 
natural and cultural plants of the world in a certain order following the purposes of the garden, educate children, students, and the public by introducing the plants to them, and also conduct scientific research on plants for different purposes (Heywood, 1987).

Gardens vary widely in their design, purpose, and features, and so it is not surprising that research has identified a wide variety of factors motivating garden visitation. These motives include the appreciation of the aesthetic and rare qualities of plants, interest in garden design and landscaping techniques used in different periods of history, admiration of gardens' scenery and 'ambiance', and pleasure in being outdoors (Connell \& Meyer, 2004). The peace and tranquility of garden spaces and their spiritual and restorative benefits have also been identified as features that attract people to public gardens (Bennett and Swasey 1996; Darwin Edwards 2000). Other reasons for visiting gardens include recreation, playing games, and social interaction (Bennett and Swasey 1996; Darwin-Edwards 2000), the desire to gain inspiration (Bennett and Swasey, 1996), and the opportunity to relax and to read (Bennett and Swasey 1996; Crilley and Price 2005). In addition to the scientific functions of botanical gardens, the fact that a city has multifaceted contributions serving the society in an "open and green space" system should always be considered as an element of planning (Demircan and Yılmaz 2004).

Istanbul is one of the most magnificent cities in Turkey with its nature and spacious green areas and has become a very fast and unhealthy city since the 1950s as a result of industrialization and immigration from Anatolia. The population of the city has increased 15 times in the past 60 years. Rapid population growth in Istanbul has brought along irregular development, and for these reasons, the number of green areas has remained below the average of world cities (Dedeoğlu and Şimşek 2006). However, the emergence of pandemics and epidemics today has increased the importance of green spaces even more. In this way, it is understood more clearly how important botanical parks, which are one of the important recreation areas, are for a metropolis like Istanbul. From this point of view, in this study, the recreational use of Bakırköy Botanical Park, which we can describe as the newest botanical park of Istanbul, is examined in the context of "recreational quality criteria" in line with the user requests and demands, its positive and negative aspects have been presented, and suggestions have been developed.

\section{Materials And Methods}

The main material of the study is Bakırköy Botanical Park, located in Bakırköy district on the European side of the city of Istanbul. The province of Istanbul is located in an extremely strategic location where the continents of Asia and Europe meet in the north of the Marmara region, between $28^{\circ} 01^{\prime \prime}$ and $29^{0} 55^{\prime \prime}$ east longitudes and $41^{\circ} 33^{\prime \prime}$ and $40^{\circ} 28^{\prime \prime}$ north latitudes With its length of about $30 \mathrm{~km}$, the Bosphorus waterway is one of Turkey's most important points connecting the European and Asian sides of Istanbul city and providing the pass from the Black Sea to the Marmara Sea (Gürel and Gündüz 2011). Bakırköy Botanical Park, which is the research material, is located within the borders of Bakırköy district of Istanbul province and was established in 2013 under Bakırköy Municipality (Fig. 1). In the park, Turkey's highest two-game towers are located with a height of 11,50 meters each and there are units such as 11 thematic gardens, 3 wind turbines, a waterfall with 8 meters high with cascading pool, view terraces, playgrounds, 
natural pond, ornamental pools, waiting areas for migratory birds, sculptures, picnic areas, social facilities, and parking lots. The energy need is met entirely by wind generators and solar energy panels. The pond of $5200 \mathrm{~m} 2$ in the park is one of the attractions of the park and supports wildlife with carps, ducks, and turtles. Moreover, Bakırköy Botanical Park has a rich plant diversity and there are approximately 262,500 plants, including monumental trees. 301 saplings planted by Bakırköy Municipality in memory of the mineworkers who lost their lives in Soma are also located in the park (Anonymous, 2020).

\section{Questionnaire design}

The questionnaire method was used in this study. In the questionnaires, the general profile of the users of Bakırköy Botanical Park, their knowledge about the concept of the botanical park, the state of recreational use, and the positive and negative features in the context of recreational quality criteria was evaluated. The questionnaires consist of a total of 22 questions, including open and close-ended questions. In the first part of the questionnaire, to determine the user profile, questions regarding the users' gender, age, occupation, education, and monthly average income, etc. were asked. In the second part, the mode of transportation, the season, day and time of the users, the frequency of arrival, and with whom the visitors came were asked as the questions to measure the knowledge of the users about the concept of the botanical park and determine the recreational use of the park. In the third part, while the positive features of the park in the context of recreational quality criteria were evaluated with the questions in four groups as comfort and image of the park, socialization, recreational functions, and transportation, negative features were evaluated in three groups as management and security, fittings and negligence, and noise. The questions asked in the context of recreational quality criteria were used on a 3-point Likert scale and organized as "I Agree", "I Partially Agree" and "I Disagree" (Kaffashi et al. 2013; Sağlık and Kelkit 2014; Başay 2018; Pirselimoğlu Batman et al. 2019; Quintal et al. 2019; Vierikko and Yli-Pelkonen 2019; Arslan and Kaymaz 2020; Sinh and Anh 2020; Shapoval et al. 2020).

\section{Sampling and data evaluation}

The sample size was calculated according to the population of Bakırköy district of Istanbul Province (Vural, 2012). The population of Bakiköy district in 2019-2020 is 229,239. (TUIK 2019). Accordingly, the sample size was calculated as 245 and a total of 250 questionnaires were conducted. The questionnaires were carried out at different times of the year, especially in spring and summer, when the park is used extensively. The questionnaires were applied to randomly selected individuals as face-to-face interviews. The surveys were conducted with the consent of the users and with their consent (Pirselimoğlu Batman et al. 2019; Kaffashi et al. 2013; Arslan and Kaymaz 2020; Sinh and Anh 2020). The data obtained from the questionnaires were evaluated using the Frequencies analysis included in the SPSS 22 package program, and the relationships between the variables were determined and interpreted by Crosstabulation, Chisquare, and Correlation analyses. Significance levels are given as * 0.05 level (2-tailed).

\section{Results}




\section{The General Profile of Users}

The questionnaire conducted in Bakırköy Botanical Park revealed that $55.60 \%$ of the participants in the questionnaire were female users and $44.40 \%$ were male users. Participants mostly came from Bakırköy and Merter districts with $20.00 \%$ and $14.00 \%$ respectively. Also, the questionnaire exhibited that the users were generally from the European side of Istanbul such as Fatih, Zeytinburnu, Avcılar, and Yenibosna. In terms of age groups, the observations showed that users between the ages of 26-35 had the highest rate with $27.0 \%$, followed by users between the ages of $36-40$ with $21.20 \%$. Observations also revealed that $42.00 \%$ of the respondents were university graduates, which is the highest percentage, $40.00 \%$ were high school graduates, $10.00 \%$ were primary education graduates and $8.00 \%$ were master/doctorate holders. Moreover, an evaluation of the occupational groups of the participants revealed that the majority of them were government officials with $29.60 \%$. The lowest rate was found to be unemployed participants with $3.20 \%$. While $28.00 \%$ of the respondents had an income of TRY $3001-4000$, the income of $26.00 \%$ was TRY $4001-5000$ and the income of $24.00 \%$ was TRY 2001-3000 (Table 1). 
Table 1

The general profile of the users

\begin{tabular}{|c|c|c|}
\hline \multicolumn{2}{|l|}{ Profile of the participants } & \multirow{2}{*}{$\begin{array}{l}\text { Percentage (\%) } \\
55.60\end{array}$} \\
\hline Gender & Female & \\
\hline & Male & 44.40 \\
\hline \multirow[t]{6}{*}{ Age } & $18-25$ & 20.80 \\
\hline & $26-35$ & 27.20 \\
\hline & $36-40$ & 21.20 \\
\hline & $41-55$ & 17.60 \\
\hline & $56-65$ & 10.40 \\
\hline & 65 and more & 2.80 \\
\hline \multirow[t]{5}{*}{ Education } & Nonliterate & - \\
\hline & Primary school & 10.00 \\
\hline & High school & 40.00 \\
\hline & University & 42.00 \\
\hline & Master/Doctorate & 8.00 \\
\hline \multirow[t]{8}{*}{ Job } & Worker & 8.80 \\
\hline & Government Official & 29.60 \\
\hline & Retired & 12.80 \\
\hline & Self-employed & 11.20 \\
\hline & Housewife & 10.40 \\
\hline & Student & 14.00 \\
\hline & Unemployed & 3.20 \\
\hline & Private sector & 10.00 \\
\hline \multirow[t]{6}{*}{ Average monthly income } & TRY 500-1000 & 6.40 \\
\hline & TRY 1001-2000 & 6.40 \\
\hline & TRY 2001-3000 & 24.00 \\
\hline & TRY 3001-4000 & 28.00 \\
\hline & TRY 4001-5000 & 26.00 \\
\hline & TRY 5001 and more & 9.20 \\
\hline
\end{tabular}




\section{Users' Information About The Botanical Park}

When the respondents were asked to define the concept of a botanical park, $44 \%$ stated that they did not know what the botanical park meant, while $56 \%$ did. When asked what botanical park means for users who know the concept of the botanical park, $42 \%$ of the respondents defined the botanical park as naturepeace, followed by the expressions of green areas and recreation with $19.6 \%$ and $18.8 \%$ respectively. (Fig. 2) While $24.4 \%$ of the participants said they knew the Nezahat Gökyiğit Botanical Garden, $64 \%$ did not respond. Besides, $50.40 \%$ of the respondents stated that they learned the botanical park through friends and acquaintances, while $2.0 \%$ stated with the least percentage that they learned through newspapers-magazines.

\section{Recreational Use Status}

An evaluation of the recreational uses of Bakırköy Botanical Park reveals that the majority of the users came by private vehicle with $42.80 \%$, followed by public transportation with $32.80 \%$ and pedestrian transportation with $18.40 \%$. While the respondents stated that they came in the summer months with the highest rate of $40.00 \%$, the lowest rate was found to be in the winter with $0.80 \%$. Moreover, when the days the botanical park was used and the frequency of arrival was questioned, the answers exhibited that it was used at the weekends with $44.40 \%$ and visited once or twice a month with $28.40 \%$. While the majority $71.20 \%$ of the respondents stated that they spent $1-3$ hours in the park, $41.60 \%$ and $41.20 \%$ stated that they came with their friends and families respectively (Table 2). 
Table 2

Recreational use of Bakırköy Botanical Park

\begin{tabular}{|c|c|c|}
\hline Recreational Use Status & & Percentage (\%) \\
\hline \multirow[t]{6}{*}{ Means / Way of Transportation } & Pedestrian & 18.40 \\
\hline & By Bicycle & 2.40 \\
\hline & By Motorcycle & 2.00 \\
\hline & By Taxi & 1.60 \\
\hline & By Private Vehicle & 42.80 \\
\hline & With Public Transportation & 32.80 \\
\hline \multirow[t]{5}{*}{ The Season Used } & Spring & 14.00 \\
\hline & Summer & 40.00 \\
\hline & Fall & 9.20 \\
\hline & Winter & 0.80 \\
\hline & Every Season & 36.00 \\
\hline \multirow[t]{4}{*}{ The Day Used } & Weekday & 14.00 \\
\hline & Weekend & 44.40 \\
\hline & Changeable & 40.80 \\
\hline & Every Day & 0.80 \\
\hline \multirow[t]{4}{*}{ Time Spent } & 0-1 hour & 11.20 \\
\hline & $1-3$ hours & 71.20 \\
\hline & $3-5$ hours & 15.20 \\
\hline & 5 hours and more & 2.40 \\
\hline \multirow[t]{7}{*}{ Frequency of Visit } & For the first time & 8.00 \\
\hline & Every Day & 7.60 \\
\hline & Once a week & 5.20 \\
\hline & Once in 15 days & 23.60 \\
\hline & Once a year & 16.80 \\
\hline & Once - twice a month & 28.40 \\
\hline & Once in two three months & 10.40 \\
\hline The Company & Alone & 12.00 \\
\hline
\end{tabular}




\begin{tabular}{|lll|}
\hline Recreational Use Status & Percentage (\%) \\
\hline & With my family & 41.20 \\
\hline With my friends & 41.60 \\
\hline With my neighbors & 5.20 \\
\hline
\end{tabular}

The relationship between the usage of recreation and the usage profile

Correlation analysis was made to determine the relationship between recreational uses of the park and the user profile, and it is shown in Table 3. As can be seen in Table 3, all factors of recreational use are related to the monthly average income levels of the users. It has been determined that there is a linear relationship between the mode of transportation, the season used, the day used and the frequency of arrival. Accordingly, the observation revealed that the users mostly preferred private car and taxi transportation to the park, and as the income level rose, the arrivals with a private vehicle increased. While it was determined that the users generally preferred the park during the summer months, it was also determined that as the income level rose, there were users who visited almost every season. Participants with an income level of TRY 4001-5000 said that they came to the park every two to three months and on weekends, while it was observed that as the income level decreased, people visited the park on different days and the frequency of arrival decreased. However, a negative relationship was found between the monthly average income level and the time spent. So much so that those with an income level of TRY 500-1000 spent 3-5 hours, while those with an income of TRY 3001-4000 spent 1-3 hours. Observations also exhibited that the educational levels of the respondents were related to other uses other than the mode of transportation. It has been observed that there is a linear relationship between education levels and season used, day used and frequency of arrival. University and high school graduates were seen to visit the park mostly in the summer, on weekends, and every two or three months. There is a negative relationship between education level and time spent. While high school graduates stated that they spent 1-3 hours, it was found that the time spent decreased with the increase in the level of education. On the other hand, a negative correlation was found between age range, time spent and frequency of arrival. That is to say, while users between the ages of 36-40 who participated in the survey came to the park every two to three months, it was observed that the frequency of coming to the park increased with the decrease in the age range. Similarly, while the participants whose age range is 65 and over spent 0-1 hour in the park, the time spent in the park increased with the decrease in the age range. According to the results of the questionnaire, while there was a positive relationship between gender and mode of transportation, the season used, and the day used, it was found to be negatively related to the time spent. Observations exhibited that female users came to the park on weekends by private vehicles, public transportation, or on foot and spent 1-3 hours in the summer. Male users, on the other hand, mostly used the park with their private vehicles almost every season and at variable times. In addition, there is a linear relationship between the occupations of the respondents and the day used. While retirees and private sector employees stated that they arrive at variable times, government officials and self-employed users said that they arrive on weekends. 
Table 3

Relationship between recreational uses and user profile (Correlation Analysis)

\begin{tabular}{|llllll|}
\hline & Gender & Age & Education & Job & Average monthly income \\
\hline Mode of Transportation & $0.000^{*}$ & 0.890 & 0.848 & 0.886 & $0.019 *$ \\
\hline Season Used & $0.023^{*}$ & 0.645 & $0.000^{*}$ & 0.043 & $0.000^{*}$ \\
\hline Day Used & $0.003^{*}$ & 0.210 & $0.004^{*}$ & $0.001 *$ & $0.031^{*}$ \\
\hline Time Spent & $-0.036 *$ & $-0.000 *$ & $-0.000^{*}$ & 0.342 & $-0.000 *$ \\
\hline Frequency of Visit & 0.391 & $-0.000 *$ & $0.000^{*}$ & 0.667 & $0.001 *$ \\
\hline * Mean diference is signifcant at the 0.05 level & & & \\
\hline
\end{tabular}

\section{An Evaluation Of Recreational Quality Criteria}

In the context of the recreational quality criteria of Bakırköy Botanical park, the respondents said that they came to get away from the crowd with the highest rate of $78.00 \%$ in terms of the comfort and image of the park and $46.80 \%$ of them stated that they agreed that it was a natural environment. While there were users who partially agreed in the opportunity to have a good time with the family with $49.60 \%$ in terms of socialization, $37.20 \%$ stated that they did not agree that since the park did not allow social interaction. In terms of recreational functions, $66.80 \%$ of the participants stated that they came for the presence of children's playgrounds, while $61.20 \%$ stated that they partially agreed with the state of the park enabling eating and drinking. The vast majority of the users with $84.40 \%$ stated that they did not agree with the situation of obtaining information about plants (Table 4). 
Table 4

Evaluation of Bakırköy Botanical Park according to recreational quality criteria

\begin{tabular}{|c|c|c|c|c|}
\hline \multicolumn{2}{|c|}{ Recreational Quality Criteria } & \multirow{2}{*}{$\begin{array}{l}\text { Agree } \\
(\%) \\
46.80\end{array}$} & \multirow{2}{*}{$\begin{array}{l}\text { I Partially } \\
\text { Agree (\%) } \\
41.20\end{array}$} & \multirow{2}{*}{$\begin{array}{l}\text { I } \\
\text { Disagree } \\
(\%)\end{array}$} \\
\hline \multirow{4}{*}{$\begin{array}{l}\text { The Comfort and } \\
\text { Image of the Park }\end{array}$} & The park is a natural environment & & & \\
\hline & The opportunity to watch the view & 10.40 & 18.80 & 70.80 \\
\hline & $\begin{array}{l}\text { The features of the area that are suitable } \\
\text { for taking photographs }\end{array}$ & 9.20 & 13.20 & 77.60 \\
\hline & To get away from the crowd & 78.00 & 15.20 & 6.80 \\
\hline \multirow[t]{2}{*}{ Socialization } & $\begin{array}{l}\text { To provide opportunity to spend time } \\
\text { with the family }\end{array}$ & 17.60 & 49.60 & 34.80 \\
\hline & To enable social interaction & 13.60 & 19.20 & 37.20 \\
\hline \multirow[t]{5}{*}{$\begin{array}{l}\text { Recreational } \\
\text { Functions }\end{array}$} & $\begin{array}{l}\text { To provide opportunities for walking, } \\
\text { having a tour, etc. }\end{array}$ & 30.40 & 31.60 & 38.00 \\
\hline & $\begin{array}{l}\text { To join organizations such as weddings, } \\
\text { festivals, etc. }\end{array}$ & 44.00 & 41.60 & 14.40 \\
\hline & $\begin{array}{l}\text { To provide opportunity for eating- } \\
\text { drinking }\end{array}$ & 12.80 & 61.20 & 26.00 \\
\hline & The existence of children's playgrounds & 66.80 & 23.20 & 10.00 \\
\hline & To obtain information about plants & 6.80 & 8.40 & 84.40 \\
\hline \multirow[t]{2}{*}{ Transportation } & The proximity to settlements & 38.80 & 50.40 & 10.80 \\
\hline & Easy transportation & 25.20 & 65.60 & 9.20 \\
\hline
\end{tabular}

The relationship between the recreational quality criteria and the user profile

A correlation analysis was performed to determine the relationship between the recreational quality criteria of the park and the user profile and is shown in Table 5. As seen in the table, it has been determined that there is a negative relationship between the park being a natural environment and age and average monthly income level.. In other words, users between the ages of 26-35 and those with an income of TRY 4001-5000 TL stated that the park was a natural environment. As the income level and age range decreased, users answered: "I Partially Agree". Also, the opportunity of the users to enjoy the view was found to be positively correlated with the education level and the characteristics worth taking pictures with the income level. As the education level and income level increased, the users answered: "I Disagree". It has been determined that the mode of transportation is linearly related to the occupation, and civil servants and students said that they partially agree with the ease of transportation to the park.. In terms of recreational functions of the park, it was determined that while obtaining information about 
plants was positively related to age, it was negatively related to occupation. In other words, as the age range got higher and users, especially government officials and students, answered: "I disagree" to the question of whether they visited the park to learn about plants or not. A negative relationship was determined between being in the park for eating and drinking purposes and the monthly average income level. As the income level increased, the users stated that they partially agreed with the purpose of visiting the park for eating and drinking. 
Table 5

Relationship between recreational quality criteria and user profile (Correlation analysis)

\begin{tabular}{|c|c|c|c|c|c|c|}
\hline \multicolumn{2}{|c|}{ Recreational quality criteria } & \multirow{2}{*}{$\begin{array}{l}\text { Gender } \\
0.945\end{array}$} & \multirow{2}{*}{$\begin{array}{l}\text { Age } \\
-\overline{0.003^{*}}\end{array}$} & \multirow{2}{*}{$\begin{array}{l}\text { Education } \\
0.055\end{array}$} & \multirow{2}{*}{$\begin{array}{l}\text { Job } \\
0.900\end{array}$} & \multirow{2}{*}{$\begin{array}{c}\text { Average } \\
\text { monthly } \\
\text { income }\end{array}$} \\
\hline $\begin{array}{l}\text { Comfort and } \\
\text { Image }\end{array}$ & $\begin{array}{l}\text { The park is a natural } \\
\text { environment }\end{array}$ & & & & & \\
\hline & $\begin{array}{l}\text { The opportunity to watch } \\
\text { the view }\end{array}$ & $0.014^{*}$ & 0.281 & $0.018^{*}$ & 0.099 & 0.087 \\
\hline & $\begin{array}{l}\text { The features of the area } \\
\text { that are suitable for } \\
\text { taking photographs }\end{array}$ & 0.309 & 0.534 & 0.206 & 0.162 & $0.026 *$ \\
\hline & $\begin{array}{l}\text { To get away from the } \\
\text { crowd }\end{array}$ & 0.511 & 0.948 & 0.540 & 0.084 & 0.657 \\
\hline \multirow[t]{2}{*}{ Socialization } & $\begin{array}{l}\text { To provide opportunity to } \\
\text { spend time with the } \\
\text { family }\end{array}$ & 0.461 & 0.204 & 0.192 & 0.058 & 0.836 \\
\hline & $\begin{array}{l}\text { To enable social } \\
\text { interaction }\end{array}$ & 0.597 & 0.134 & 0.575 & 0.660 & 0.478 \\
\hline \multirow[t]{5}{*}{$\begin{array}{l}\text { Recreational } \\
\text { Functions }\end{array}$} & $\begin{array}{l}\text { To provide opportunities } \\
\text { for walking, having a tour, } \\
\text { etc. }\end{array}$ & 0.825 & 0.146 & 0.051 & 0.126 & 0.241 \\
\hline & $\begin{array}{l}\text { To join organizations } \\
\text { such as weddings, } \\
\text { festivals, etc. }\end{array}$ & 0.142 & 0.148 & 0.230 & 0.878 & 0.315 \\
\hline & $\begin{array}{l}\text { To visit the park for eating } \\
\text { and drinking }\end{array}$ & 0.581 & 0.512 & 0.192 & 0.281 & $-0.024^{\star}$ \\
\hline & $\begin{array}{l}\text { The existence of } \\
\text { children's playgrounds }\end{array}$ & 0.575 & 0.199 & 0.480 & 0.463 & 0.915 \\
\hline & $\begin{array}{l}\text { To obtain information } \\
\text { about plants }\end{array}$ & 0.202 & $0.040 *$ & 0.706 & $-0.001 * \star$ & 0.887 \\
\hline \multirow[t]{2}{*}{ Transportation } & $\begin{array}{l}\text { The proximity to } \\
\text { settlements }\end{array}$ & 0.567 & 0.336 & 0.194 & 0.519 & 0.593 \\
\hline & Easy transportation & 0.535 & 0.758 & 0.753 & $0.049 *$ & 0.407 \\
\hline
\end{tabular}

Considering the negative aspects and shortcomings of the park in the recreational use of Bakırköy Botanical Park, in terms of management and security, users stated that they partially agreed with the competence of the security personnel with the highest rate of $66.00 \%$. This was followed by users who responded "I partially agree" to the night use question with $45.60 \%$. When the outfit elements and negligence were questioned, the highest rate was $36.40 \%$ of the participants who said that WCs were 
sufficient, while $54.80 \%$ of the respondents partially agreed with the negligence of children's playgrounds. This was followed by the users who stated that they partially agreed with the sufficiency of pergola and seating units with $50.40 \%$. Besides, the highest rate of participants $(67.20 \%)$ stated that they did not agree with the presence of garbage in the park. The evaluation in terms of noise revealed that the highest rate was $57.20 \%$ of the users who stated that they did not agree with the idea that the park was crowded (Table 6).

Table 6

Negative aspects and deficiencies of Bakırköy Botanical Park

\begin{tabular}{|c|c|c|c|c|}
\hline \multicolumn{2}{|c|}{ Negative aspects and deficiencies } & \multirow{2}{*}{$\begin{array}{l}\begin{array}{l}\text { I agree } \\
(\%)\end{array} \\
23.20\end{array}$} & \multirow{2}{*}{$\begin{array}{l}\text { I partially } \\
\text { agree (\%) } \\
66.00\end{array}$} & \multirow{2}{*}{$\begin{array}{l}\text { I disagree } \\
\text { (\%) }\end{array}$} \\
\hline Management and & Lack of security personnel & & & \\
\hline & Lack of baffle plates & 40.40 & 42.00 & 17.60 \\
\hline & $\begin{array}{l}\text { Places in the park being } \\
\text { expensive }\end{array}$ & 22.80 & 43.20 & 34.00 \\
\hline & $\begin{array}{l}\text { Lack of plant identification } \\
\text { cards }\end{array}$ & 36.40 & 42.40 & 21.20 \\
\hline & Night use of the park & 18.80 & 45.60 & 35.60 \\
\hline \multirow[t]{7}{*}{$\begin{array}{l}\text { Outfit elements and } \\
\text { negligence }\end{array}$} & $\begin{array}{l}\text { Negligence of children's } \\
\text { playgrounds }\end{array}$ & 31.20 & 54.80 & 14.00 \\
\hline & $\begin{array}{l}\text { Sufficiency of lighting } \\
\text { elements }\end{array}$ & 12.40 & 48.80 & 38.80 \\
\hline & $\begin{array}{l}\text { Sufficiency of pergola and } \\
\text { seating units }\end{array}$ & 24.40 & 50.40 & 25.20 \\
\hline & Negligence of park paths & 12.00 & 34.00 & 54.00 \\
\hline & Negligence of the pond area & 22.00 & 36.40 & 41.60 \\
\hline & Insufficiency of WCs & 36.40 & 34.00 & 29.60 \\
\hline & $\begin{array}{l}\text { Existence of garbage in the } \\
\text { park }\end{array}$ & 13.60 & 19.20 & 67.20 \\
\hline \multirow[t]{2}{*}{ Noise } & Park being very crowded & 5.20 & 37.60 & 57.20 \\
\hline & Existence of traffic noise & 18.40 & 32.80 & 48.80 \\
\hline
\end{tabular}

\section{The Relationship Between The Negative Aspects And Deficiencies}

Correlation analysis was made to determine the relationship between the user profile of the negative aspects of the park and is shown in Table 7. As seen in Table 7, an evaluation of the management and 
safety of the park in the context of recreational quality criteria exhibited that the lack of baffle plates had a negative relationship with age, education, and monthly average income and participants, who were university graduates between the ages of 26-35, answered "I Partially Agree", and as the age range increased, the users answered, "I Agree". Participants with an income level of TRY 4001-5000, on the other hand, said "I Agree" and as their income level decreased, they said, "I Partially Agree". On the other hand, it has been determined that the night use of the park is negatively related to gender, the lack of security staff is negatively related to age, the lack of plant identification cards is negatively related to education, while the expensiveness of the places in the park is positively related to age and education. Moreover, female users stated that they partially agreed in the night use of the park, while users between the ages of 26-35 and high school graduates stated that they partially participated in the lack of security staff and the lack of plant identification cards. As the age range decreased and the education level increased, users stated that they agreed. Expensive places in the park were expressed by users between the ages of 36-40 and high school graduates as "I Partially Agree".

While negligence of children's playgrounds in terms of outfit elements and negligence was negatively associated with age, education, and monthly income, it was found to be positively related to the profession. University graduates, government officials, participants between the ages of 26-35, and the ones with an income level of TRY 3001-4000 stated that they partially participated in the negligence of children's playgrounds, as the age range increased, the users said: "I agree". It has been determined that the inadequacy of lighting elements is negatively related to age and gender, the neglect of the pond area is negatively related to education and occupation, the inadequacy of WCs to occupation, and the presence of garbage in the park is negatively related to age. While female users and users between the ages of 26-35 stated that they partially agreed with the insufficiency of the lighting elements, as the age range increased, the users answered "I disagree". Similarly, the users in the age range of 26-35 stated that they did not agree with the presence of garbage in the park, and as the age range increased, the users said "I Partially Agree". Also, while university graduates and government official users partially agreed with the negligence of the pond area, high school graduates, retirees, and self-employed persons stated that they disagreed. Government officials agreed with the insufficiency of the WCs and housewives stated that they partially agreed. The presence of traffic noise in the park was negatively associated with age and positively associated with the profession. Thus, users in the age range of 26-35 answered that they did not agree with the presence of traffic noise, and they partially agreed as the age range increased. In terms of occupational group, it was observed that while government official users partially agreed with the presence of traffic noise, student users did not. 
Table 7

Relationship between the negative aspects and deficiencies with the user profile (Correlation Analysis).

\begin{tabular}{|c|c|c|c|c|c|c|}
\hline \multicolumn{2}{|c|}{ Negative aspects and deficiencies } & Gender & Age & Education & Job & $\begin{array}{l}\text { Average } \\
\text { monthly } \\
\text { income }\end{array}$ \\
\hline \multirow[t]{5}{*}{$\begin{array}{l}\text { Management and } \\
\text { Security }\end{array}$} & $\begin{array}{l}\text { Lack of security } \\
\text { personnel }\end{array}$ & 0.539 & $-0.001 *$ & 0.874 & 0.264 & 0.475 \\
\hline & Lack of baffle plates & 0.564 & $-0.000 \star$ & $-0.000 *$ & 0.098 & $-0.000 *$ \\
\hline & $\begin{array}{l}\text { Places in the park } \\
\text { being expensive }\end{array}$ & 0.198 & $0.048^{\star}$ & $0.025^{\star}$ & 0.935 & 0.147 \\
\hline & $\begin{array}{l}\text { Lack of plant } \\
\text { identification cards }\end{array}$ & 0.317 & 0.092 & $-0.000 *$ & 0.812 & $0.001^{*}$ \\
\hline & Night use of the park & $-0.039 *$ & -0.009 & -0.031 & 0.261 & -0.021 \\
\hline \multirow[t]{7}{*}{$\begin{array}{l}\text { Outfit elements } \\
\text { and negligence }\end{array}$} & $\begin{array}{l}\text { Negligence of } \\
\text { children's playgrounds }\end{array}$ & 0.683 & $-0.000 *$ & $-0.000 *$ & $0.007^{\star}$ & $-0.000 *$ \\
\hline & $\begin{array}{l}\text { Insufficiency of } \\
\text { lighting elements }\end{array}$ & $-0.018 *$ & $-0.012^{\star}$ & 0.135 & 0.506 & 0.356 \\
\hline & $\begin{array}{l}\text { Sufficiency of pergola } \\
\text { and seating units }\end{array}$ & 0.734 & 0.817 & 0.913 & 0.366 & 0.055 \\
\hline & $\begin{array}{l}\text { Negligence of park } \\
\text { paths }\end{array}$ & 0.227 & 0.086 & 0.781 & 0.084 & 0.569 \\
\hline & $\begin{array}{l}\text { Negligence of the } \\
\text { pond area }\end{array}$ & 0.538 & 0.778 & $-0.010^{\star}$ & $-0.006^{\star}$ & 0.602 \\
\hline & Insufficiency of WCs & 0.098 & 0.746 & 0.093 & $-0.006^{*}$ & 0.119 \\
\hline & $\begin{array}{l}\text { Existence of garbage } \\
\text { in the park }\end{array}$ & 0.188 & $-0.007 *$ & 0.883 & 0.573 & 0.922 \\
\hline \multirow[t]{2}{*}{ Noise } & $\begin{array}{l}\text { Park being very } \\
\text { crowded }\end{array}$ & 0.077 & 0.854 & 0.725 & 0.605 & 0.564 \\
\hline & $\begin{array}{l}\text { Existence of traffic } \\
\text { noise }\end{array}$ & 0.430 & $-0.009 * *$ & -0.038 & $0.026^{\star}$ & 0.934 \\
\hline
\end{tabular}

\section{Discussion And Conclusion}

Today, the changes in the social and economic situation directly affect the quality of urban life and the preferences of living spaces (Sağlık and Kelkit 2014). It is important to consider the danger of exceeding the carrying capacity limit with the intensive use on these areas and to make recreational plans (Pirselimoğlu Batman et al. 2019). In this study, the user profile of Bakırköy Botanical Park was determined and the meaning of the Botanical Park for the users and the recreational usage status of the 
park were questioned. Moreover, in the context of recreational quality criteria, the positive and negative features of the park and also whether it met the user requests were determined. Similarly, different researchers emphasized that it is necessary to evaluate the views of people using a recreation area about this area and that the attitudes, perceptions and preferences of those using the area are the prerequisites for ensuring the quality of recreation in recreational areas (Fischler, 2000; Talay et.al. 2010). In the questionnaire, Bakırköy Botanical park was observed to be generally preferred by the users of the European side of Istanbul, also the users were mostly female, a young user group between the ages of 2635 , the majority of the users were university graduates, had a monthly income of TRY 3001-4000 monthly income and were government official users. Although the users knew the concept of "Botanical Park", there was no botanical park known to most of them with $64.00 \%$. It was concluded that only $24.4 \%$ of the users knew about the Nezahat Gökyiğit Botanical Garden. Users expressed the concept of Botanical Park in different ways. It was observed that they mostly expressed it as nature-peace, followed by the expressions of a green area and recreation. Similary, Ballantyne et al. (2008) stated in the example of a botanical garden that the users were mostly between the ages of 30-39 and liked to be outdoors, while Bonnie and Mak (2019) stated that the parks were mostly visited by the residents.

The users must make optimum use of the area in a way that will serve the demands and needs of various age groups, gender, education levels, and occupational groups (Borrie and Birzell 2001). Also, user needs are shaped according to recreational uses, and needs are shaped according to uses (Aksoy and Akpınar 2011). An evaluation of the recreational usage situation of Bakırköy Botanical park with the study revealed that the usage was generally intense in the summer months and the users came by private car and taxi. University and high school graduate users, who were mostly earning TRY 4001-5000, were determined to come to the park on weekends, and the level of income was effective in visiting the park. As the income level decreased, the park was visited on different days and the frequency of arrival decreased. On the other hand, it was observed that the users between the ages of 26-35 visited the park and stayed between 1-3 hours. Although the frequency of coming to the park varies according to occupational groups, retirees and private sector employees stated that they arrived at different times, while government officials and self-employed people generally used the park on weekends. As a matter of fact, in different studies, it has been emphasized that the users spend mostly 1-2 hours in the parks and are generally used in good weather and summer months (Bonnie and Jim 2019; Zafri et al. 2019).

Recreational activities differ according to cultures and nations (Sasidharan 2002). In examining the quality of public open spaces, the way the user perceives the space and space's responses to the user's needs are important. Parks should offer different uses to the users, provide ease of transportation (accessibility), be safe, well-groomed, and attractive (comfort and image), and give people the opportunity to be together (Öztürk and Temel 2019). In our study, in the context of the recreational quality criteria of Bakırköy Botanical Park, the most important feature of the park in terms of comfort and image is that it is a quiet and calm park that people come to get away from the crowd. Access to the park is relatively easy, and $65.60 \%$ of users reported that they partially agreed that the park had easy access. Children's playgrounds in Bakırköy Botanical Park were also considered an important recreational function for the users by allowing them to spend time with the family in terms of socialization. Users stated that they did 
not agree with the situation of obtaining information about plants as a botanical park. This situation is due to the lack of an identifying label for every plant in the botanical park. The eating and drinking state of the park was found to be important in terms of recreational function and especially high-income users partially agreed with the park's eating and drinking situation. The park is in an easily accessible location, private car or taxi transportation is used extensively and that state was associated with the professional group. Government officials and student users, on the other hand, partially agreed with the ease of access to the park. As in previous studies, Knapp et al. (2019) stated that elements such as landscape, shrubs, trees, gardens and water features add attractiveness and are important regarding the quality of the park, while Karaşah and Var (2016) stated that in the example of Nezahat Gökyiğit Botanical Garden, users are generally preferred to get away from the crowd.

Moreover, in our study, the users emphasized that the botanical park had some deficiencies in terms of recreational quality criteria. One of the most important deficiencies of the park is WCs, one of the outfit elements. In terms of management and security, the lack of security personnel was concluded and the users partially agreed with the park's night use status. In terms of outfit elements and maintenance, most users partially agreed with the negligence of children's playgrounds and the adequacy of pergolas and seating units. On the other hand, the respondents emphasized that the park was not very crowded and there was no traffic noise. Although Bakırköy Botanical Park is near the E-5 highway, the presence of noise is prevented by the presence of a tree zone as the sound barrier. When the negative aspects of the park were associated with the user profile, especially female users partially agreed with the night usage state of the park in terms of management and security. Regarding the lack of baffle plates, university graduates between the ages of 26-35 partially agreed. The inadequacy of WCs in terms of outfit elements and maintenance was related to the profession and government officials stated that WCs were insufficient, while housewives partially agreed. The negligence of children's playgrounds was another deficiency and this situation was found to be related to profession, age, and income level. Namely, while young users between the ages of 26-35, who were university graduates and had TRY 3001-4000 income level, partially agreed with the negligence of children's playgrounds, and the result "I Agree" was obtained as the age range increased. On the other hand, although there was no noise situation in the park, especially young users and students between the ages of 26-35 were the groups who stated that there was no traffic noise. However, as the age range increased, some users answered "I Partially Agree" with the presence of noise. Similarly, in the studies conducted in different parks, it was emphasized that the users were worried about toilet and waste management and that the security was insufficient when using the park (Onsekiz and Emür 2008; Zafri et al. 2019). On the other hand, Larondelle and Haase (2017) stated that while people were wandering through the urban forest, they sought a managed infrastructure in toilets and trash cans.

In the questionnaire study conducted in Bakırköy Botanical Park, which is located within the borders of Istanbul Metropolitan, Bakırköy district and has the characteristics of an urban park, the requests and expectations of the users visiting the park were questioned and the park was determined as a park that can meet the active and passive recreational needs of its users. The park was observed to offer possibilities such as seeing natural scenery, getting away from the crowd, exploring, etc. While the park 
offers opportunities for active recreation with children's playgrounds, walking areas, wedding areas, eating and drinking venues, and activities carried out during certain periods of the year, it also has the feature of improving the quality of life. Also, it supports the wildlife with the artificial pond and the scenery presented by the water element. On the other hand, although the park is easily accessible, public transportation should be increased to support government officials and student users. As the users emphasized, it is necessary to eliminate the deficiencies of the outfit elements in the park (increase the number of ground-direction signs, toilets, and lighting elements, etc.) and their maintenance should be carried out regularly. On the other hand, by increasing the lighting elements for female users, the use of the park at night will be offered. Unfortunately, it is seen that Bakırköy Botanical Park does not fully meet the expectations regarding education and research. With the survey studies conducted, it is seen that the users perceive this area as a standard park and visit it for the physical and spiritual contributions it provides to people. For Bakırköy Botanical Park to fulfill its functions as a botanical park in its full sense, the 'Plant Identification Labels' with Latin-Turkish names, origins, and family names on each plant, together with its recreational features, must be included and brochures, which introduce the botanical park to the visitors, should be handed. It should be distributed within. Especially for visually impaired individuals, it would be appropriate to implement the mechanisms with audio-narration. Again, the awareness of the botanical park should be increased by organizing one-day tours to introduce the plants by experts at certain times for educational purposes in the park. Considering the intensive user population of Botanical Parks, which offer rich beauties from natural parts, ensuring that they can healthily reach future generations is another important issue to be taken into consideration. For this to come true, removing and improving the negative features of Bakırköy Botanical Park in terms of recreation, ensuring the protection-use balance, and protecting the rich and invaluable plant taxa it contains will be an important approaches in terms of sustainability.

\section{Declarations}

\section{Acknowledgements No}

Funding: No funding

Author contrubution Nilufer SEYIDOGLU AKDENIZ and S. Doganay YENER contributed equally at every stage of the article.

Ethics approval The surveys in the article were made with the consent of the people. This situation is written in the method section. Ethics committee certificate was not required.

Conflict of interest/competing interests The authors declare no confict of interest or competing interests.

\section{Consent to participate: No}

Consent for publication Yes. We confrm that this work is original and has not been published elsewhere. 


\section{References}

1. Aksoy V, Akpinar A (2011) Research about public green area use and green area demand in Istanbul Fatih district. Istanbul Commerce Univ. Journal. of Science, 20: 81-96.

2. Anonymous (2020) Botanic Park. https://www.bakirkoy.bel.tr/bakirkoy/botanik-parki.html. Accessed 31 May 2020.

3. Arslan ES, Kaymaz I (2020) Visitor perception of recreational ecosystem services and their role in landscape management of Gölcük Nature Park, Turkey International Journal of Sust. Dev.\&World Ecol. 27: 202-213. https://doi.org/10.1080/13504509.2019.1711247.

4. Ballantyne R, Packer Hughes K (2008) Environmental Awareness, Interests and Motives of Botanic Gardens Visitors: Implications for Interpretive Practice. Tourism Manag. 29: 439444. https://doi.org/10.1016/j.tourman.2007.05.006.

5. Basay S (2018) Urban people's perceptıons of organıc products and theır attıtudes: An example from Turkey. Fresenıus Environ. Bull. 27 (5A):3854-3862.

6. Bennett ES, Swasey JE (1996) Perceived stress reduction in urban public gardens. Hort. Technology. 6 (2): 125-128. https://doi.org/10.21273/HORTTECH.6.2.125.

7. Borrie WT, Birzell RM (2001). Approaches to measuring quality of the wilderness experience. http://www.fs.fed.us/rm/pubs/rmrs p020/rmrs_p020 029 038. Accessed 25 July 2020.

8. Chiesura A (2004), The role of urban parks for the sustainable city. Landscape and Urban Plann. 68 (1): 129-138. https://doi.org/10.1016/j.landurbplan.2003.08.003.

9. Connell J, Meyer D (2004) Modeling the visitor experience in the gardens of Great Britain. Current Issues in Tourism. 7 (3): 183-216. https://doi.org/10.1080/13683500408667979.

10. Crilley G, Price B (2005) The Adelaide Botanic Gardens visitor service quality survey. Adelaide: Centre for Environmental and Recreational Management, University of South Australia.

11. Darwin-Edwards I (2000). Education by stealth: The subtle art of educating people who didn't come to learn. Roots. 20 (7): 37-40.

12. Şimşek Mi, Dedeoğlu i (2010). İstanbul'da budama çalışmaları ve dünya kentleri örnekleri. Kent ağaçları. Kent ağaçları ve süs bitkilerinde bakım ve budama esasları. İBB Basımevi İstanbul.

13. Demircan N, Yılmaz H (2004) Erzurum kentinde botanik bahçesi oluşturulması üzerine bir araştırma. Atatürk Üniv. Zir. Fak. Der.35:193-200.

14. Fischler R (2000) Planning for social betterment: from standart of living to quality of life, Urban planning in a changing world, The Twentieth-Century Experience. 183 pp. London.

15. Gurel A, Gunduz AE (2011) İstanbul'un ekolojik yapısı üzerine bir araştırma. Marmara sosyal araş. Dergi. 1: 1-12

16. Hepcan ÇC, Ozkan B (2005) Determination of the facilities and services of botanic gardens as an urban open spaces. Journ. of Ege Univ. Fac. of Agric. 42:159-170 
17. Heywood VH (1987). The changing role of the botanic garden. In Bramwell, D., Hamann, O., Heywood, V. and Synge, H. (eds), Botanic Gardens and the World Conservation Strategy, pp. 3-18. Academic Press, London.

18. Kaffashi S, Shamsudin MN, Radam A., Rahim KA, Yacobe MR (2013) We are willing to pay to support wetland conservation: local users' perspective. International Journal of Sustain. Develop. \& World Ecol. 20: 325-335. https://doi.org/10.1080/13504509.2013.800612.

19. Kalugin YG, Musinova LP, Volchanskaya AV (2019) Open ground collections of Saint Petersburgg botanic garden for the benefit of botanic and environmental education. International scientific and practical conference. "Agro SMART - Smart solutions for agriculture", KnE Life Sci. pp. 956967. https://doi.org/10.18502/kls.v4i14.5695.

20. Karaşah B, Var M (2016) Determination of visitor preferences in botanic gardens 'Case of Nezahat Gokyigit Botanic Garden. Kastamonu Univ. J. of Forest. Fac. 16:120-130.

21. Knapp M, Gustat J, Darensbourg R, Myers L, Johnson C (2019) The relationships between park quality, park usage, and levels of physical activity in low-Income, African American neighborhoods. International Journal of Environ. Res. Pub. Health. $16: 85$ https://doi.org/10.3390/ijerph16010085.

22. Larondelle N, Haase D (2017) Back to nature! Or not? Urban dwellers and their forest in berlin. Urban Ecosys. 20: 1069-1079.

23. Lee TH, Shen YL (2013) The influence of leisure involvement and place attachment on destination loyalty: evidence from recreationists walking their dogs in urban parks. Journal of Environ. Psych. 33: 76-85. https://doi.org/10.1016/j.jenvp.2012.11.002.

24. Mak BKL, Jim CY (2019) Linking park users' socio-demographic characteristics and visit-related preferences to improve urban parks. Cities. 92: 97-111. https://doi.org/10.1016/j.cities.2019.03.008.

25. Mat Nazir NN, Othman N, Nawawi AH (2014) Green infrastructure and its roles in enhancing quality of life. Procedia-Social and Behav. Sci. 153: 384-394. https://doi.org/10.1016/j.sbspro. 2014.10.071.

26. Miller D, Merrileesa B, Coghlanb A (2015) Sustainable urban tourism: understanding and developing visitor pro-environmental behaviors, J. of Sustain. Tour. (23): 26-

48. https://doi.org/10.1080/09669582 2014.912219.

27. Türkyılmaz Tahta B, Gülgün Aslan B (2018) Botanical gardens: the scientific, visual and recreational contributions to urban life. MSU J. of Sci. 6: 519-528.

28. Onsekiz D, Emür SH (2018) Determınatıon of user preferences and evaluatıon crıterıa ın cıty parks. J. of Erciyes Univ. Institute of Soc. Sci. 24: 69-104.

29. Öztürk SM, Temel SC (2019) Evaluation of quality criteria in urban parks: The Case of Karabük Kordon Park, Kent Akademisi 12: 752-764.

30. Pirselimoglu Batman Z, Özer P, Ayaz E (2019) The evaluation of ecology-based tourism potential in coastal villages in accordance with landscape values and user demands: the Bursa-MudanyaKumyaka case. International J. of Sustain. Develop. \& World Ecol. 26: 166-

178. https://doi.org/10.1080/13504509. 2018.1508525. 
31. Quintal VA, Lwin M, Phaui I, Lee S (2019) Personality attributes of botanic parks and their effects on visitor attitude and behavioral intentions. J. of Vacation Mark. 25: 176192. https://doi.org/10.1177/ 1356766718760089.

32. Razak MAW, Othman N, Mat Nazir NN (2016) Connecting people with nature: urban park and human well-being, Procedia - Soc. and Behavior. Sci. 23: 476 - 484. https://doi.org/10.1016/j.sbspro. 2016.05.138.

33. Saglik A, Kelkit A (2014) A study on the Influence of Çanakkale urban parks on life quality. COMU J. Agric. Fac. 2: 43-55.

34. Sasidharan V (2002) Special Issue Introduction: understanding recreation and the environment within the context of culture. Leisure Sci. 24: 1-11. : https://doi.org/10.1080/01490400252772809.

35. Shapoval V, Rivera M, Croes R (2020) The quality of gardens tourism and the visitor experience: differentiating between first time and repeat visitors. Annals of Leisure Res. https://doi.org/10.1080/ 11745398.2020.1744174.

36. Sin NH, Anh THP (2020) Push and pull factors impacting visitors' loyalty: A case of Saigon Zoo and Botanical Gardens. J. of Sci. Ho Chi Minh City Open Univ. 10:120-135.

37. Stanford D, Guiver J (2016) Driving pro-environmental change in tourist destinations: encouraging sustainable travel in National Parks via partnership project creation and implementation, J. of Sustain. Tourism 249: 484-505. https://doi.org/10.1080/09669582.2015.1122018.

38. Talay İ, Kaya F, Belkayalı N (2010) Sosyo-ekonomik yapının rekreasyonel eğilim ve talepler üzerine etkisi: Bartın Kenti Örneği. Coğrafi Bil. Derg. 8: 147-156.

39. TUIK (2019) Bakırköy İlçe Nüfusu. Türkiye İstatistik Kurunu. https://www.tuik.gov.tr/ Accessed 25 June 2021. Turna I, Yazıcı F, Atar F (2017) Evaluation of pruning works on urban trees in Istanbul province. J. of Bartin Fac. of Forest. 19: 1-10.

40. Vierikko K, Yli- Pelkonen V 2019 Seasonality in recreation supply and demand in an urban lake ecosystem in Finland. Urban Ecos. 22: 769-783

41. Vural H (2012)Tarım ve gıda ekonomisi istatistiği. Bursa: Uludağ Üniversitesi Ziraat Fakültesi Ders Notları No: 107.

42. Zafri NM, Jahangir A, Prithuli AA, Sharmin N, Islam I. (2019) Who uses urban parks? a study of user characteristics and activity patterns of Ramna Park, Dhaka. Int. J. of Architec. and Urban Develop. 9: 5-14.

\section{Figures}




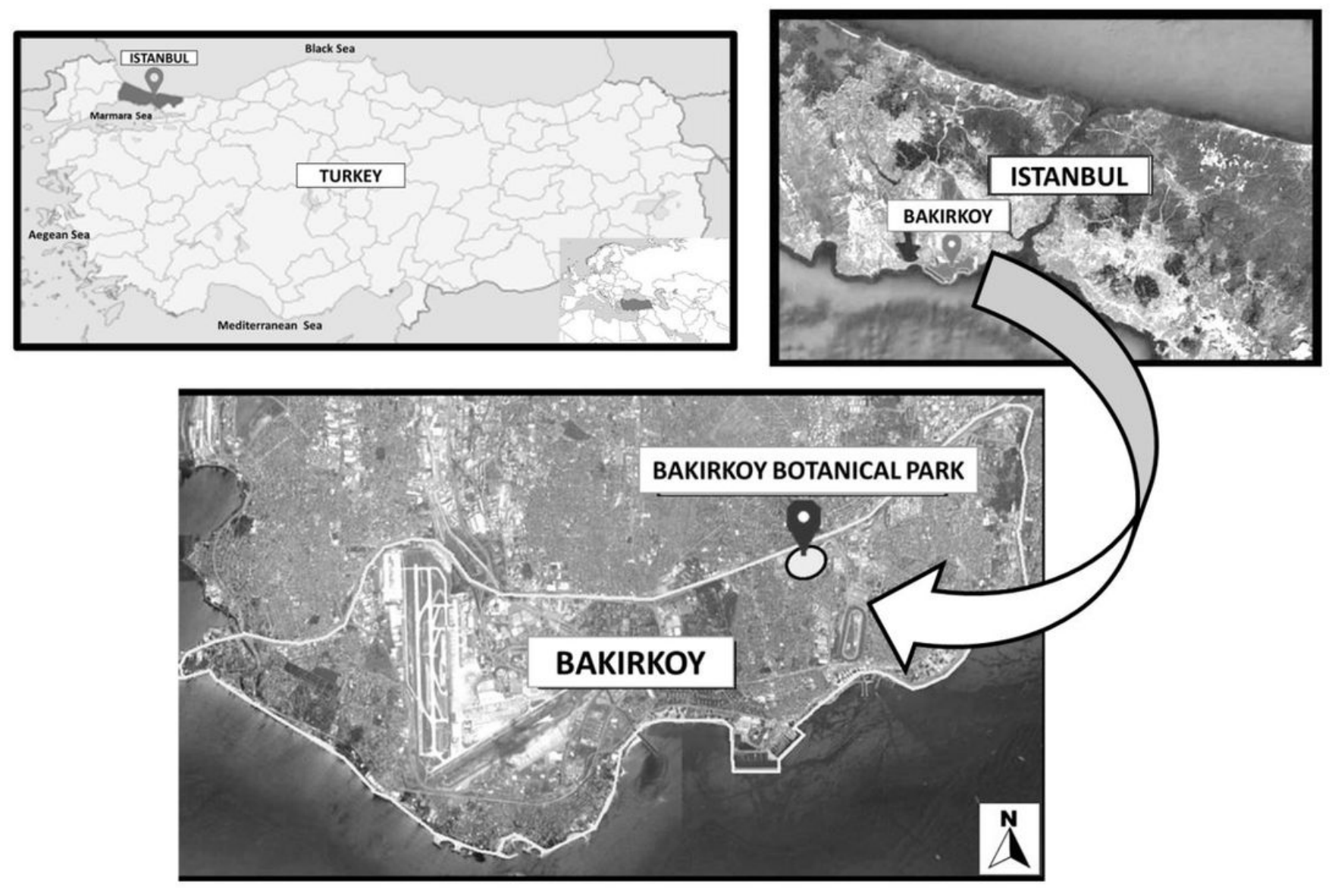

Figure 1

Location of Istanbul and Bakırköy Botanical Park 


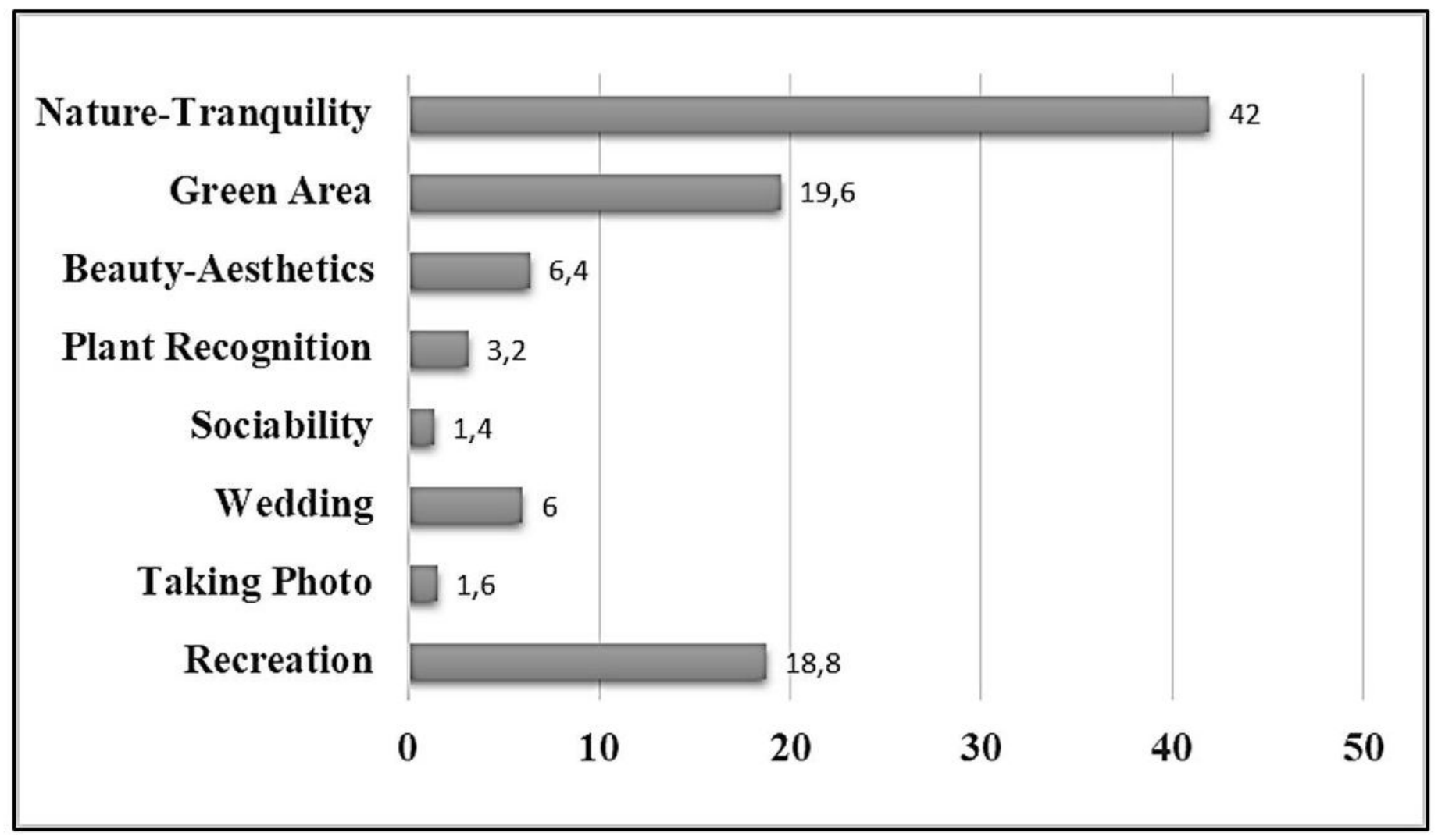

Figure 2

The meaning of the botanical park for users 